\title{
Influence of grassland and feeding management on technical and economic results of dairy farms
}

\author{
C.W. ROUGOOR ${ }^{1,2, *}$, T.V. VELLINGA ${ }^{1}$, R.B.M. HUIRNE ${ }^{2}$ AND A. KUIPERS ${ }^{1}$ \\ ${ }^{1}$ Research Station for Cattle, Sheep and Horse Husbandry, Runderweg 6, \\ NL-8219 PK Lelystad, The Netherlands \\ 2 Department of Economics \& Management, Wageningen Agricultural University, \\ Hollandseweg 1, $6706 \mathrm{KN}$ Wageningen, The Netherlands \\ * Corresponding author. Current address: CLM, P.O. Box 10015, NL-3505 AA Utrecht, \\ The Netherlands; fax: +31-30-2441318; e-mail: crougoor@clm.nl
}

Received 17 July 1998; accepted 14 September 1999

\begin{abstract}
A field study of 38 dairy farms was set up to determine the relationships between feeding management, grassland management and feed costs per $100 \mathrm{~kg}$ of milk, 305-day milk production, and nitrogen surplus per ha. Data of the farms were (among other things) on management (based on questionnaires), grassland calendar, milk production and economic data for the period of May 1996 to May 1997. Partial Least Squares (PLS) was used to analyze the data, because of the large number of variables relative to the number of farms. The $\mathrm{R}^{2}$ of the models ranged between 0.32 (nitrogen surplus model) and 0.60 (feed costs model). The nitrogen surplus model did not have predictive relevance. The PLS-model for feed costs resulted in the hypotheses that (1) a high percentage of pasture that cannot be grazed by the cows results in an increase in feed costs, (2) a high percentage of grazings lasting longer than 4 days increases feed costs, (3) mistakes in set-up of the paddocks cannot be compensated for by exact planning, and (4) farmers who have not organized their grazing management well, also tend to have worse results as to their silage management. The milk production model showed that a high milk production per cow is realized on farms with too low a number of growing days for cutting.
\end{abstract}

Keywords: economics, grassland, feeding, management, milk production, nitrogen surplus, partial least squares

\section{Introduction}

The current paper is part of a project with the purpose of getting a better insight into relationships between management, 305-day milk production and economic results. During the past couple of years, net farm income has decreased on Dutch dairy farms, partly due to a declining milk price. However, differences in gross margin (i.e.gross returns minus feed costs from purchased feed per unit of milk) between 
farms are rather big (Rougoor et al., 1997). Differences in grassland and feeding management are expected to have an important effect on gross margin, because of its influence on the feed costs. Therefore, optimizing grassland and feeding management might be a way to maximize economic results. In literature, only few references can be found on the relationships between management of grassland, milk production, and economic results. Moreover, most of the literature focuses on just one aspect of these relationships. Fisher \& Roberts (1995), for instance, examined the effects of grazing intensities on milk production per cow in the UK. Fisher \& Dowdeswell (1995) studied the effects of different grazing systems on herbage intake and milk production in the UK. In Denmark Kristensen et al. (1997) found that a high grazing intensity had a negative effect on milk production and live weight gain. Dobbelaar et al. (1992) determined the relationship between initial sward height and the number of days the cows grazed in the same paddock, whereas Hanson et al. (1998) studied the profitability of moderate intensive grazing systems compared with extensive grazing systems. These results, however, are hard to compare, due to differences in grazing practices between countries.

Rotational grazing is the most commonly used grazing practice in the Netherlands. Essential characteristics of a rotational grazing system are that paddocks are grazed during a limited number of days, with the purpose to offer cows a sequence of paddocks with 1,500-2,000 kg DM grass per ha. Boxem (1982) stated that paddocks being grazed for a period of 4 days at a max is optimal. Second characteristic is that grass not needed for grazing is cut for conservation (Dobbelaar, 1988). Higher grazing intensity or reduced grass growth in the Netherlands lead to a lower cutting percentage and not to a limited herbage allowance. A shortage of roughage for the winter period is compensated by buying more roughage or concentrates. In the $\mathrm{UK}$, on the contrary, silage making is independent of grazing. In that case, a higher grazing intensity results in a limited herbage allowance.

Gross margin is expressed per $100 \mathrm{~kg}$ of milk, because the total amount of milk produced is the limiting factor by the milk quota system. Because of legal restrictions on environmental pollution per ha in the Netherlands, mineral surplus should be minimized as well. Therefore, the influence of management on nitrogen surplus is also studied. In the current study variance in milk quota per ha is limited between farms. In that case a minimization in mineral surplus per $\mathrm{kg}$ of milk is almost equal to a minimization per ha. Therefore, mineral surplus is expressed per ha, in accordance with the way legal restrictions are formalized in the Netherlands.

There is no literature available on the relationship between feeding management and economic results. Literature on the relationship between feeding management and milk production is more common. Waheed et al. (1977) investigated the relationship between 20 feeding management factors and milk production. Gibson (1984) reviewed 23 papers on the relation between frequency of feeding and milk production. He concluded that the average increase in milk production was $2.7 \%$ as a response to increased frequency of feeding. However, all these papers differed regarding feeding frequencies that were compared, making it hard to draw a useful conclusion. Sargeant et al. (1997) analysed data of 500 questionnaires on the relationships between management and milk production. Differences in grazing and 
feeding systems make it difficult to compare the results of these different studies. Besides that, almost all studies have only considered one isolated aspect of grassland or feeding management and the effect of this on milk production. No study was found where the influence of grassland and feeding management on milk production as well as on economic results was studied intensively.

The objective of the current study was to analyze the different segments as mentioned above, and to determine the influence of grassland and feeding management on feed costs, milk production and nitrogen surplus for the situation in the Netherlands. The objective of this paper has been split into three topics:

1. How is milk production related to grassland management and feeding management?

2. How are feed costs related to grassland management and feeding management?

3 . How is nitrogen surplus related to grassland management and feeding management?

Not much information was available beforehand, and many factors are interrelated. Therefore, the ultimate goal of the study was to define some hypotheses regarding these relations. First, selection of farms and data recording is described, and an introduction of the methodology discussed. The feed costs model is worked out in detail. Results of the analyses and their statistical power are discussed. The model results on milk production and nitrogen surplus are not worked out completely, but are discussed in general. The hypotheses that have been formulated are described in the second part of the results section.

\section{Materials and Methods}

\section{Selection of farms}

This study is part of a bigger study. For the study as a whole, 39 dairy farms were selected on the basis of gross margin of May 1993 to May 1994 (for farms using a noncalendar year accounting period) or January 1994 to January 1995 (for farms using a calendar year accounting period), and the 305-day milk production between August 1993 and August 1994. Rougoor et al. (1997) showed that milk quota per ha has a great influence on gross margin per $100 \mathrm{~kg}$ of milk. Therefore, only farms were selected with a milk quota per ha between 10,500 to $14,500 \mathrm{~kg}$. To maximize differences between farms in gross margin and milk production, farms with average values for these variables were excluded; farms were selected out of the 'tails' of the normal distribution. Farms had to meet the following 2 criteria:

1. A gross margin below DFL 77.40 or above DFL 78.40 per $100 \mathrm{~kg}$ of milk;

2. A 305-day milk production below $7270 \mathrm{~kg}$ per cow, or above $7450 \mathrm{~kg}$.

This way, a data set was created with maximum difference between farms for milk production and gross margin. Eight farms were 'low' on both, 9 farms had a low gross margin and a high 305-day milk production, 10 farms had a high gross margin and a low 305-day milk production, and 12 farms were high on both. The grassland management is expected to influence feed costs, but effects on gross returns will be small. 
Therefore, this part of the study is focusing on feed costs instead of gross margin.

Rougoor et al. (1999a) showed that, unfortunately, the differences in gross margin between the four groups mentioned above have become much smaller over the past few years. The groups could not clearly be recognized anymore. Therefore, the analyses were done on individual data, without differentiating between the four groups. During the period of data collection one farm dropped out, so analyses are based on data of 38 farms.

\section{Data recording}

The farms were visited monthly during the period of May 1996 to May 1997. Table 1 shows the different kinds of collected information on grassland and feeding management. Classification of data collection is based on Rougoor et al. (1998). Some technical data could be obtained from institutions which collect these data in a systematic way. Besides these existing data, technical data were collected by single on-farm investigations and long term on-farm observations, i.e. repetitive data collection throughout the year. An example of a single on-farm investigation is the amount of silage harvested form the pasture. Long term on-farm observations relate mostly to data that were collected and kept up-to-date by the farmer, like on the grassland calendar, recording the activities on the pasture: cutting, grazing, fertilizing, etc.

Information on decision making in the different areas was gathered by questionnaires and interviews. The questionnaires focused on management functions, i.e. planning, implementation and control. Additionally, management was measured during an evening workshop (an off-farm experiment). The farmers were asked to write down their business goals in general and the critical success factors of the different research areas. This was done as described in detail by Huirne et al. (1997).

The questionnaire on grassland management included questions on grazing, fertilizing, planning the use of the paddocks, maintenance of pasture, harvesting, and as-

Table 1. Type of data collection from May 1996 to May 1997.

\begin{tabular}{|c|c|c|c|c|}
\hline Subject & $\begin{array}{l}\text { Existing } \\
\text { farm data }\end{array}$ & $\begin{array}{l}\text { Single on-farm } \\
\text { investigations }\end{array}$ & $\begin{array}{l}\text { Long term on-farm } \\
\text { observations }^{1)}\end{array}$ & Off-farm experiments \\
\hline \multicolumn{5}{|c|}{ Management } \\
\hline - overall & & Questionnaire & & Business goals \\
\hline - grassland & & Interview & & Critical success factors \\
\hline - feeding & & Interview & & Critical success factors \\
\hline \multicolumn{5}{|l|}{ Technical } \\
\hline - grassland & $\mathrm{GIBO}^{2)}$ & Sward height & Grassland calendar & \\
\hline - feeding & $\mathrm{Blgg}^{3)}, \mathrm{GIBO}$ & Amount of silage & Feed purchase & \\
\hline Economic & GIBO & & & \\
\hline
\end{tabular}

\footnotetext{
${ }^{1)}$ Repetitive data collection throughout the year

2) GIBO group, accountancy agency

${ }^{3)}$ Laboratory for soil and crop testing (Blgg Oosterbeek)
} 
pects taken into account by the farmer to judge the quality of the paddocks. The questionnaire on feeding management focused on the supply of colostrum, rearing of calves, planning of the use of silage, feeding of dried-off cows, planning of the concentrate use and minerals and the evaluation of feeding strategies by the farmer. 'Home grown' silage was analysed by standard lab techniques. The amount of dry matter (DM), and amount of VEM (energy-standard in a net energy system; Van Es, 1978) and DVE (sum of digestible feed and microbial true protein available in the small intestine; Tamminga et al., 1994) per kg of DM were measured. The amount of silage harvested from the pasture was estimated by volume. An overview of nitrogen and phosphorus input and output was made on the basis of the information on purchases of concentrates, fertilizers, etc. Data on milk production were obtained from the Royal Dutch Cattle Syndicate (NRS) and included 3 to 6 weekly milk productions on a per cow basis. Economic results were obtained from the GIBO group, one of the major Dutch accountancy agencies.

\section{Descriptive statistics}

Almost all farms in our data set used rotational grazing. A first selection of the data was based on simple linear correlation between management variabels and milk production, feed costs and nitrogen surplus. Goal variables are the 305-day milk production (i.e. the farm average 305-day milk production from May 1996 till May 1997), feed costs per unit of milk for that period, and nitrogen surplus in $\mathrm{kg} \mathrm{N}$ per ha. Only variables that had a correlation of $\leq-0.25$ or $\geq 0.25$ with a 305 -day milk production, gross margin or nitrogen surplus were selected for the multivariate analyses. In this way, only 27 variables out of a total of more than 200 related to grassland or feeding management were selected for the multivariate model on feed costs. Table 2 shows some general information on the farms.

\section{Choice of statistical method}

Path-analysis is a useful technique to elucidate webs of causation in a multivariate data set (Erb et al., 1981). However, with 'farm' being the unit of measurement, the

Table 2. Average and the standard deviation (SD) of the selection criteria (305-day milk production and gross margin) and other farm specific variables for May 1996 to May 1997 for the 38 farms included in the study.

\begin{tabular}{lcc}
\hline & Average & $\mathrm{SD}$ \\
& & 764 \\
Average 305-day milk production (kg) & 8,342 & 5.00 \\
Average gross margin (DFL/100 kg milk) & 65.10 & 12.6 \\
Farm size (ha) & 42.2 & 14 \\
Milk quota (*1,000 kg per farm) & 518 & .5 \\
Number of labour equivalents at the farm & 1.6 & 7.3 \\
No. of days cows graze in the same paddock & 6.9 & 24 \\
No. of days cows are housed per year & 175 & \\
\hline
\end{tabular}


current data set has only 38 cases. In that case the 'standard' path analysis will run out of degrees of freedom. Partial Least Squares (PLS) is a statistical method that can deal with this problem. PLS is considered especially useful for constructing prediction equations when there are many explanatory variables and comparatively few sample data (Garthwaite, 1994). Other advantages of PLS for a complex data set as such, are that PLS has the possibility of analysing complex path-models, it accounts for multicollinearity and no assumptions have to be made regarding the distribution of the variables (it is a distribution-free methodology) (Rougoor et al., 1999b) The intention of PLS is to form so-called latent variables (LVs) which capture most of the information in the $\mathrm{X}$-variables that is useful for predicting the Y-variables. This way, the dimensionality of the regression problem is reduced, because fewer LVs are used than the number of $\mathrm{X}$-variables.

A null-path model with the LVs and their relationships has to be constructed. This null-path model includes all the relations that will be tested. Using prior knowledge and intuition the investigator is free to specify the LVs out of the X-variables, and to design the relations between the LVs (Wold, 1985). An arrow scheme can be used to show the expected relationships between the LVs. Arrows between LVs in the scheme represent hypothetical relationships. The relationships between the LVs are given by the path coefficients, ranging from -1 tot +1 . The relations between the $\mathrm{X}$ variables and their LV is expressed in the factor loading, which can very between -1 and +1 (Steenkamp \& Van Trijp, 1996). The factor loadings are estimated in such a way that the LV-estimates are optimal towards the X-variables as well as to the Yvariables. The optimization criterion is minimization of residual variances. PLS seeks values for the factor loadings and path coefficients that minimize residual variance for the LVs and the X- and Y-variables. PLS estimation algorithm proceeds in three stages, which have been described in detail by Steenkamp \& Van Trijp (1996) and Wold (1985).

\section{Statistical power of PLS}

Because no distributional assumptions are made in PLS, the traditional statistical testing methods based upon assumptions about statistical distributions are not well suited. The average variance extracted (AVE) measures the amount of variance of the X-variables that is captured by the LV. The AVE can vary form 0 to +1 . A high AVE indicates that the amount of variance captured by the LV is big compared with the amount of unexplained variance of the $\mathrm{X}$-variables. This indicates that the $\mathrm{X}$ variables are useful explaining variables. Fornell \& Larcker (1981) suggest that AVEs of the LVs should be greater than the correlations among the LVs to fully satisfy the requirements for discriminant validity. The $\mathrm{R}^{2}$ measures the explanatory power of the relations between the different LVs. It shows how well an LV is predicted by other LVs. This value can also vary between 0 and 1 . The Stone Geisser test criterion, $\mathrm{Q}^{2}$, indicates how well the observed Y-variables can be reconstructed by the model. It can be used to evaluate the predictive relevance of the model. It has a value between -1 and $+1 . Q^{2}>0$ indicates that there is predictive relevance, whereas $\mathrm{Q}^{2}<0$ suggests lack of relevance. There are different kinds of $\mathrm{Q}^{2}$ measures. In the 
current study the blindfolding redundancy measure was used (Fornell \& Cha, 1994).

The PLS model was estimated with the LVPLS 1.8 program (Lohmöller, 1987). Path-models were set up for milk production, feed costs and nitrogen surplus. The model of feed costs showed the most interesting results, and is discussed in detail. The results of the other 2 path-models are discussed in general.

\section{Basic PLS model for feed costs}

Table 3 shows the variables, with a description, that were included in the model. The specification of the LVs is based upon a logical separation of different parts and levels of feeding and grassland management. Eight LVs were included in the model, with 'Feed costs' being the goal variable, and the other LVs explanatory variables. These explanatory LVs partly concern management ('Decision Making' and 'Business Goals'), partly set-up of the farm ('Farm'), and are partly technical ('Silage making', 'Grazing', 'Feeding' and 'Feed purchasing'). These LVs were used in the path-analysis.

The LVs are not independent. This dependency is put into the model by arrows. To define a null-path model, the framework as described by Rougoor et al. (1998) was used. The decision-making process (business goals and decision making) influences biological and technical aspects and processes (grazing, silage making, feeding, and feed purchasing). These aspects and processes can also influence one another (it was assumed, for instance, that grazing would influence the amount of feed purchased) and the feed costs per $100 \mathrm{~kg}$ of milk. The relationships that have been included in the null-path model are shown in Figure 1.

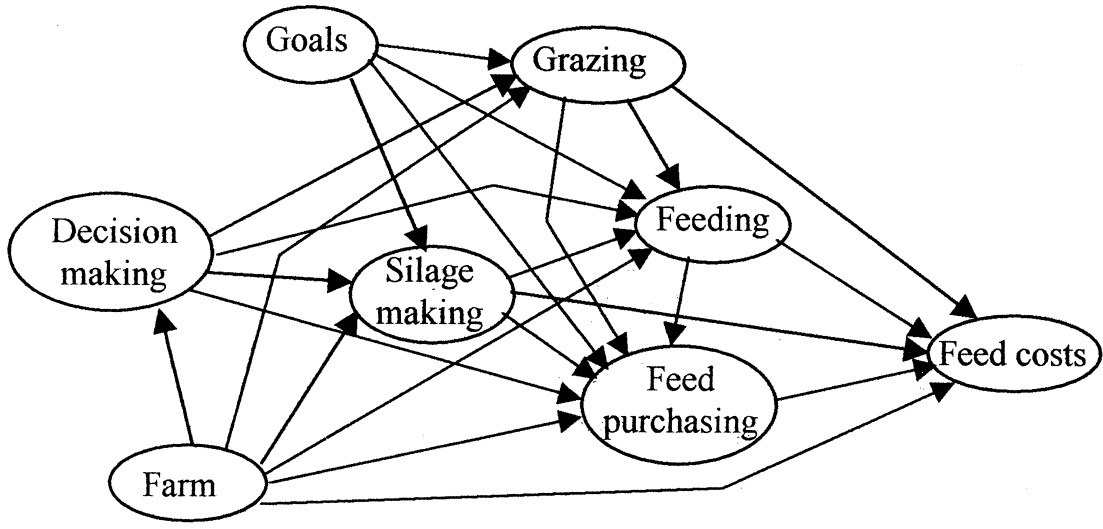

Figure 1. Null-path model of the PLS-modelling. 


\section{C.W. ROUGOOR, T.V. VELLINGA, R.B.M. HUIRNE AND A. KUIPERS}

Table 3. Description of variables used in the analysis with feed costs being the goal variable.

\begin{tabular}{|c|c|c|c|}
\hline Latent Variable & $\mathrm{X}$ - or Y-variable & Description of X- or Y-variable & Avg. Value \\
\hline Farm & $\begin{array}{l}\text { Corn \% } \\
\text { Intensity } \\
\text { Pasture no grazing }\end{array}$ & $\begin{array}{l}\text { Percentage of land used for corn for silage } \\
\text { GVE per ha }{ }^{1)} \\
\text { Percentage of pasture that cannot be used for grazing } \\
\text { by the dairy cows (because of distance or barriers) }\end{array}$ & $\begin{array}{l}12 \% \\
2.12 \mathrm{GVE} \\
21 \%\end{array}$ \\
\hline $\begin{array}{l}\text { Decision Making } \\
\text { (DM) }\end{array}$ & $\begin{array}{l}\text { Plan week } \\
\text { Grassland imp }\end{array}$ & $\begin{array}{l}\text { Number of weeks pasture use is planned in advance } \\
\text { Importance of grassland management for earning } \\
\text { money according to the farmer, on } 1 \text { (unimportant) } \\
\text { to } 6 \text { (important) scale }{ }^{2)} \\
\text { Estimate of farmer of VEM-contents of 'home grown' } \\
\text { silage at the farm compared with VEM-contents of } \\
\text { silage at other farms }{ }^{3)} \\
\text { No. of aspects farmer takes into account regarding pro- } \\
\text { blems with feeding (i.e. changes in herd, weather, feed } \\
\text { ration, grazing) } \\
\text { No. of aspects farmer takes into account regarding pur- } \\
\text { chase of corn silage (i.e. price, ratio balance, experience) }\end{array}$ & $\begin{array}{l}1.71 \\
1.62\end{array}$ \\
\hline Business Goals & $\begin{array}{l}\text { Goal silage } \\
\text { Goal contract work } \\
\text { Goal soil }\end{array}$ & $\begin{array}{l}\text { Importance of goal 'improve quality 'home grown' } \\
\text { silage' according to the farmer }{ }^{4)} \\
\text { Importance of goal 'decrease amount of contract work' } \\
\text { Importance of goal 'improve soil quality'4) }\end{array}$ & $\begin{array}{l}3.91 \\
2.27 \\
3.67\end{array}$ \\
\hline Silage making & $\begin{array}{l}\text { VEM } \\
\text { Cutting\%-1 } \\
\text { Wilting period } \\
\text { Cutting-July }\end{array}$ & $\begin{array}{l}\text { Amount of VEM per kg 'home grown' silage } \\
\text { Cutting percentage of first cut } \\
\text { Average number of days between cutting and ensiling } \\
\text { Number of growing days for cutting stage in the period } \\
20 \text { June - } 20 \text { July }\end{array}$ & $\begin{array}{l}886 \\
46.6 \% \\
1.6 \text { days } \\
29.9 \text { days }\end{array}$ \\
\hline Grazing & $\begin{array}{l}\text { Grazing-June } \\
\text { Flexible } \\
\text { Grazing-grazing } \\
\text { Grazing-cutting } \\
\text { Grazing > } 4 \text { days } \\
\text { Min surface }\end{array}$ & $\begin{array}{l}\text { Number of growing days for grazing stage in the period } \\
20 \text { May till } 20 \text { June } \\
\text { Use of flexible fencing for grazing ( } \% \text { of all grazings) } \\
\% \text { grazing followed by grazing }{ }^{5} \\
\left.\% \text { grazing followed by cutting, and cutting }=>\text { grazing }^{5}\right) \\
\% \text { grazings that lasted longer than } 4 \text { days } \\
\text { surface of smallest paddock for milking cows }\end{array}$ & $\begin{array}{l}21.3 \text { days } \\
38.9 \% \\
47 \% \\
44 \% \\
57 \% \\
1.3 \text { ha }\end{array}$ \\
\hline Feeding & $\begin{array}{l}\text { Conc/cow } \\
\text { Push on }\end{array}$ & $\begin{array}{l}\mathrm{Kg} \text { of concentrates given per cow per year } \\
\text { Times a day feed is pushed on towards the animals }\end{array}$ & $\begin{array}{l}2335 \mathrm{~kg} \\
2.8 \text { times }\end{array}$ \\
\hline Feed purchasing & $\begin{array}{l}\text { N-conc-ha } \\
\text { N-roughage-ha } \\
\text { P-conc-ha } \\
\text { P-roughage-ha }\end{array}$ & $\begin{array}{l}\text { Purchases of } \mathrm{N} \text { from concentrates in } \mathrm{kg} \text { per ha } \\
\text { Purchases of } \mathrm{N} \text { from roughage in } \mathrm{kg} \text { per ha } \\
\text { Purchases of } \mathrm{P}_{2} \mathrm{O}_{5} \text { from concentrates per kg per ha } \\
\text { Purchases of } \mathrm{P}_{2} \mathrm{O}_{5} \text { from roughage per kg per ha }\end{array}$ & $\begin{array}{r}98 \mathrm{~kg} \\
14 \mathrm{~kg} \\
37 \mathrm{~kg} \\
4 \mathrm{~kg}\end{array}$ \\
\hline Feed costs & Feed costs & Costs of purchased feed per $100 \mathrm{~kg}$ of milk & DFL. 16.11 \\
\hline
\end{tabular}

1) $\mathrm{GVE}=$ Dutch 'cow equivalent unit'; $1 \mathrm{cow}=1 \mathrm{GVE} ; 1$ heifer $=.439 \mathrm{GVE} ; 1$ calf $=.220 \mathrm{GVE}$.

2) The farmer was asked to order management in the areas of feeding, grassland, fertility, animal health, milk production and culling as to importance

3) Value between -100 (total underestimation of own results) and 100 (total overestimation of own results).

4) A score of 1 indicates not important at all, a score of 5 indicates very important.

$\left.{ }^{5}\right)($ grazing - grazing $)+($ grazing - cutting $)+($ cutting - grazing $)+($ cutting - cutting $)=100 \%$ (advice: alternative grazing and cutting). 


\section{Results}

Feed Costs

\section{Outcome of the model}

Table 4 provides the factor loadings for each of the measures, the $\mathrm{R}^{2}$ of each LV and the variance extracted for each of the $\mathrm{X}$ - and Y-variables, as well as the average variance extracted (AVE) for each of the LVs. The $\mathrm{R}^{2}$ shows that $60 \%$ of the variance in feed costs can be explained from the 7 explanatory LVs. Table 4 shows that AVEs are high for the LVs 'Business goals', 'Feeding', and 'Feed purchasing', indicating that a large amount of the variance in het X-variables is captured by the LV. Unfortunately, the other explanatory LVs have small AVEs, indicating a relatively great variance due to measurement errors.

Figure 2 shows a graphical representation of the structural parameters in the feed costs model. Only relationships with path-coefficients $>0.20$ or $<-0.20$ were included in the final model. The LV 'Decision making' is highly related to 'Grazing' and 'Silage making', and, via these 2 LVs, to feed costs. 'Feed purchasing' is a central element in the model. The LVs 'Farm', 'Grazing', 'Feeding' and 'Silage making' are related to it. As could be expected, 'Feed purchasing' is highly related to feed costs.

The significance of the model can be determined by the average variance extracted (AVE), the $\mathrm{R}^{2}$, and the $\mathrm{Q}^{2}$. Table 5 shows the outcome of the different variables for the feed costs model as well as for the other models, which are not discussed in detail here. The feed costs model turns out to have the highest explanatory value of the inner model; the $\mathrm{R}^{2}$ and the $\mathrm{Q}^{2}$ are the highest for this model. The AVEs do not differ much between models. On average, the models have rather low AVEs. So, the requirements for discriminant validity could not be satisfied completely for this model. The model on nitrogen surplus has a negative value for $\mathrm{Q}^{2}$, so this model has no predictive relevance. Therefore, this model was not used in the second part of the research; the formulation of hypotheses.

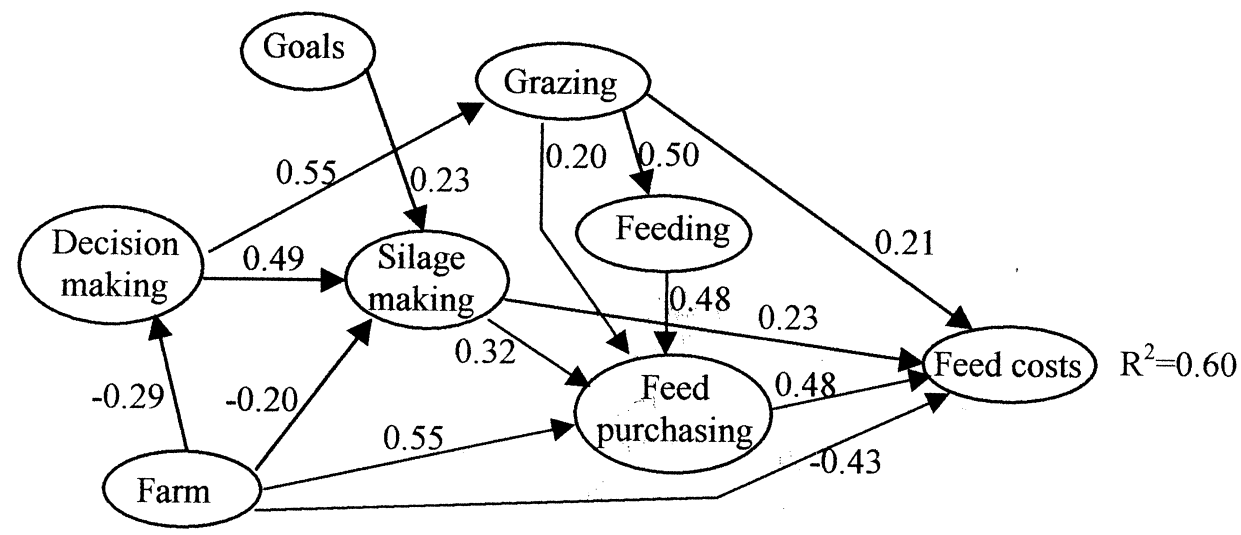

Figure 2. Inner structural path coefficients of feed costs model. 


\section{C.W. ROUGOOR, T.V. VELLINGA, R.B.M. HUIRNE AND A. KUIPERS}

Table 4. Outcome of the PLS model for feed costs being the goal variable.

\begin{tabular}{|c|c|c|c|}
\hline $\begin{array}{l}\text { Latent Variable } \\
\qquad X \text {-or Y-Variable }\end{array}$ & Factor Loading & Mult. R ${ }^{2}$ & $\begin{array}{l}\text { (Average) Variance } \\
\text { Extracted }\end{array}$ \\
\hline Farm & & $\mathrm{NA}^{1)}$ & 0.41 \\
\hline Corn \% & 0.69 & & 0.48 \\
\hline Intensity & 0.48 & & 0.23 \\
\hline Pasture no grazing & -0.71 & & 0.51 \\
\hline Decision Making & & 0.08 & 0.27 \\
\hline Plan week & 0.39 & & 0.15 \\
\hline Grassland imp & -0.72 & & 0.52 \\
\hline Know-how VEM & 0.42 & & 0.18 \\
\hline Feeding aspects & 0.65 & & 0.42 \\
\hline Corn aspects & 0.24 & & 0.06 \\
\hline Business Goals & & NA & 0.58 \\
\hline Goal silage & 0.77 & & 0.60 \\
\hline Goal contract work & 0.77 & & 0.59 \\
\hline Goal soil & 0.73 & & 0.54 \\
\hline Silage making & & 0.43 & 0.30 \\
\hline$V E M$ & 0.20 & & 0.04 \\
\hline Cutting\%-1 & 0.73 & & 0.53 \\
\hline Wilting period & 0.66 & & 0.43 \\
\hline Cutting-July & 0.43 & & 0.18 \\
\hline Grazing & & 0.30 & 0.39 \\
\hline Grazing-June & 0.42 & & 0.18 \\
\hline Flexible & 0.25 & & 0.06 \\
\hline Grazing-grazing & -0.79 & & 0.63 \\
\hline Grazing-cutting & 0.68 & & 0.46 \\
\hline Grazing $>4$ days & 0.72 & & 0.51 \\
\hline Min surface & 0.71 & & 0.51 \\
\hline Feeding & & 0.25 & 0.64 \\
\hline Conc/cow & 0.82 & & 0.68 \\
\hline Push on & -0.78 & & 0.60 \\
\hline Feed purchasing & & 0.62 & 0.47 \\
\hline$N$-conc-ha & 0.88 & & 0.77 \\
\hline$N$-roughage-ha & 0.47 & & 0.23 \\
\hline P-conc-ha & 0.84 & & 0.70 \\
\hline P-roughage-ha & 0.45 & & 0.21 \\
\hline Feed costs & & 0.60 & $\mathrm{NA}^{2)}$ \\
\hline Feed costs & $1.00^{3)}$ & & \\
\hline
\end{tabular}

1) NA = not available; this LV was not predicted by any other LV

${ }^{2)}$ not available; only single indicator.

${ }^{3)}$ constrained to one (single indicator). 
Table 5.Value of different parameters to interpret the statistical power of the models.

\begin{tabular}{lllr}
\hline & $\mathrm{AVE}^{1)} \min / \max$ & $\mathrm{R}^{2}$ goal parameter & $\mathrm{Q}^{2}$ \\
Feed costs & $0.27 / 0.64$ & 0.60 & 0.42 \\
Milk production & $0.27 / 0.57$ & 0.50 & 0.15 \\
Nitrogen surplus & $0.28 / 0.67$ & 0.32 & -0.12 \\
\hline
\end{tabular}

1) Average Variance Extracted

\section{Influence of farm structure}

The LV 'Farm' plays an important role in the feed costs model. This LV is determined by the intensity of the farm, measured in GVE per ha, the percentage of land in use for corn, and the percentage of the pasture that cannot be used for grazing by the cows, due to distance or barriers between barn and paddock (a highway for instance). This variable has a direct negative relationship with feed costs. So, farms with little pasture that can be grazed by the cows have a lower score on the LV 'Farm', resulting in higher feed costs. To get more insight into which aspects of the feed costs are related to the variable 'Pasture no grazing', this variable is related to different aspects of the feed costs. It turned out that farms with more pasture that cannot be grazed by the cows spent more money on purchasing silage. It is unclear why they bought more silage: they had the same amount and quality of silage from their own farm, and they did not have a higher milk quota per ha. The variable 'Pasture no grazing' was not included in the models of milk production and gross margin, because correlation was too low. So, 'Pasture no grazing' has no influence on milk production and the effect on gross margin (via the feed costs) has partly vanished.

'Farm' is positively related to 'Feed purchasing'. So, farms with a lower score on the LV 'Farm' buy less feed per ha, but, as stated before, the feed costs per $100 \mathrm{~kg}$ of milk are higher. This seems contradictory, but can be explained by the intensity of the farm. Farms with a high number of GVE per ha, score high on 'Farm' as well. Per ha they have to buy more feed (so the LV 'Feed purchasing' is higher), but per kg of milk they need to buy less feed (so the feed costs are lower). So, despite the small variety in intensity between farms, it still has an impact on the economic results. 'Intensity' and 'Pasture no grazing' are variables of the same LV. Their mutual correlation, however, is small $(-0.16)$. So, the relationship between 'Pasture no grazing' and feed costs is not due to differences in intensity between farms with much pasture and little pasture that cannot be grazed by the cows respectively.

The LV 'Farm' is also related to the LV 'Silage making'. Farms with much pasture that cannot be grazed by the cows have a higher cutting percentage in the first cut ('Cutting\%-1') and the average wilting period ('Wilting period') is longer. Another variable of the LV 'Silage making' is 'VEM'. This variable, however, got a very low factor loading and AVE. So, notwithstanding the path coefficient from the LV 'Farm' to the LV 'Silage making', no conclusions can be drawn on a possible effect of the LV 'Farm' on the quality of silage. The LV 'Silage making', in turn, is related 
to feed costs. However, the low factor loading shows that this is only for a very small part the result of a lower silage quality. Most of the relationship between 'Silage making' and 'Feed costs' can be ascribed to differences in wilting period and cutting percentage of the first cut. Higher values for these variables are related to higher feed costs.

\section{Grassland management}

The LV 'Grazing' includes the variables 'Grazing > 4 days', and 'Min surface'. These two variables are related to each other (correlation is 0.49 ). The grazings last too long, because the paddock size is too big. The model shows that this is related to higher feed costs. The LV 'Grazing' is also highly related to the LV 'Decision making'. This LV can be seen as a representative of a certain attitude towards grassland management. The variables included in this LV give insight into the broader view of the farmer regarding grassland management. Farmers who take many aspects into account regarding problems with feeding, who think that grassland is not that important for earning money, but still plan the use of their paddocks many weeks ahead and have a good knowledge about the quality of their silage, score high on this LV. So, in spite of the fact they think pasture is not that important, they seem to plan quite well. However, these farmers have higher feed costs, partly due to the higher score on the LV 'Grazing'. So, the hypothesis can be formulated that mistakes in setup of the paddocks cannot be compensated for by exact planning. Besides that, it indicates that farmers should not underestimate the importance of grassland management for economic results. An underestimation will result in poorer grassland management and higher feed costs.

In the null-path model (Figure 1) only relationships that can be expected from a biological point of view were included or relationships that could be based on common knowledge. A relationship between 'Grazing' and 'Silage making' was not included, for we expected independence between these two aspects. The correlation between the two LVs, however, turns out to be 0.31 . It supports the finding that grassland management is an attitude of the farmer that is reflected in different aspects of farm management; in grazing management as well as in silage management. Farmers who organize their grazing management well (the paddocks are the right size), will also have better results as to their silage management (a shorter wilting period). This results in lower feed costs per $100 \mathrm{~kg}$ of milk (roughage costs as well as costs of concentrates). No influence was found on milk production or gross margin. These relationships are shown in Table 6, where the 38 farms are split into 19

Table 6.Average value of grassland variables of 38 farms divided into 2 groups, based on percentage of grazings lasting longer than 4 days.

\begin{tabular}{lllll}
\hline $\begin{array}{l}\text { Grazing } \%> \\
4 \text { days }\end{array}$ & $\begin{array}{l}\text { VEM silage } / \mathrm{kg} \\
\mathrm{DM}\end{array}$ & $\begin{array}{l}\text { DVE silage (g/ kg } \\
\mathrm{DM})\end{array}$ & $\begin{array}{l}\text { Wilting period } \\
\text { (days) }\end{array}$ & $\begin{array}{l}\text { Feed costs }(\mathrm{DFL}) / \\
100 \mathrm{~kg} \text { of milk }\end{array}$ \\
35 & 898 & 78.2 & 1.5 & 14.78 \\
80 & 877 & 74.2 & 1.8 & 17.50 \\
\hline
\end{tabular}


farms with the lowest grazing percentage $>4$ days and 19 farms with the highest grazing percentage $>4$ days.

\section{Milk production}

Figure 3 shows the path coefficients of the model on a 305-day milk production. Because of limited space, the set-ups of the LVs will not be discussed in detail, but some aspects highlighted. The model includes the number of growing days for grazing in June and for cutting in June, July and August, as a representation of grassland management. These variables are grouped together in the LV 'Growing days'. All variables have a positive factor loading on this LV, with numbers of growing days for cutting and grazing in June being the variables with the highest factor loadings. The LV 'Growing days' is negatively related to production (correlation is -0.42 ). This implicates that farms with more growing days have a lower milk production. Growing days for grazing in June was included in the feed costs model as well. In this model, a positive relation with feed costs is found, indicating a negative relation with gross margin. However, an economically optimal number of growing days is expected. Before this optimum, the relationship between growing days and feed ocsts would be negative and after this optimum the relation is expected to have a positive sign. The model, however, cannot trace this, because in the PLS-analysis only linear relationships are included. As a result, the model showed a weak linear relationship; factor loading and extracted variance of the variable 'Grazing-June' are low.

Combining the models of feed costs and milk production arrives at the conclusion that farms with a high milk production have a number of growing days that is lower than optimal from an economic point of view. The advantage of a higher milk production for the feed costs (i.e. less feed necessary for maintenance) has disappeared because the grass is cut at too young a stage. So, farms that realize a high milk production per cow might be afraid of a decreasing quality of their grass; they actually use grass that is too young. They want to avoid the risk of waiting too long resulting in the grass quality getting too low. As a result of that, energy and protein content is high, but quantity is suboptimal. This especially holds for ensiled grass, which is

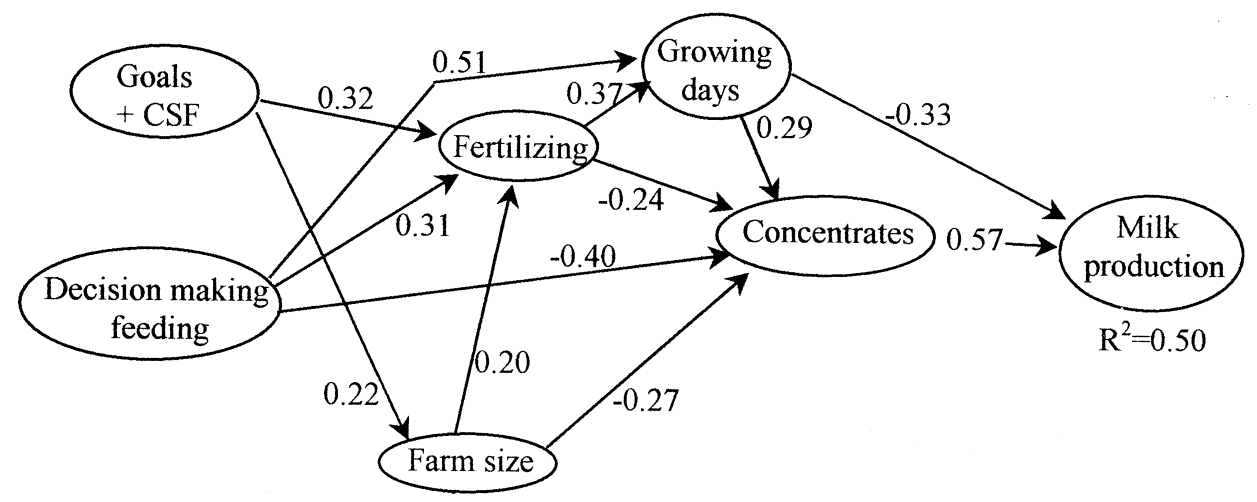

Figure 3. Inner structural path coefficients of 305-day milk production model. 
Table 7. Average values of grassland variables for 38 farms divided into three groups based on number of growing days for cutting in June.

\begin{tabular}{llllllll}
\hline $\begin{array}{l}\text { Growing } \\
\text { days cutting } \\
\text { June (days) }\end{array}$ & $\begin{array}{l}\text { No. of } \\
\text { farms }\end{array}$ & $\begin{array}{l}\text { Milk } \\
\text { quota } \\
(\mathrm{kg} / \mathrm{ha})\end{array}$ & $\begin{array}{l}\text { VEM } \\
\text { silage } / \\
\mathrm{kg} \mathrm{DM}\end{array}$ & $\begin{array}{l}\text { DVE } \\
\text { silage }(\mathrm{g} / \\
\mathrm{kg} \mathrm{DM})\end{array}$ & $\begin{array}{l}\text { Quantity } \\
\text { of silage } \\
\left(\mathrm{m}^{3} / \mathrm{cut} / \mathrm{ha}\right)\end{array}$ & $\begin{array}{l}\text { Milk } \\
\text { production } \\
(\mathrm{kg} / 305-\mathrm{d})\end{array}$ & $\begin{array}{l}\text { Gross margin } \\
(\mathrm{DFL} / 100 \\
\mathrm{kg} \mathrm{milk})\end{array}$ \\
19.6 & 13 & 13,401 & 903 & 79.2 & 9.7 & 8,557 & 64.98 \\
27.8 & 12 & 12,936 & 891 & 76.0 & 10.4 & 8,358 & 66.60 \\
39.3 & 13 & 12,142 & 864 & 72.7 & 13.9 & 8,091 & 63.83 \\
\hline
\end{tabular}

harvested too young. The correlation matrixes partly support this. The correlation between growing days for cutting in June and VEM and DVE-contents of the silage is -0.40 and -0.39 respectively. So, younger grass has a better quality. The amount of silage that is harvested per cutting per ha is indeed higher for older grass: a correlation between growing days in June for cutting and this amount is 0.40 . Unfortunately, it is not possible to make a direct comparison between growing days and total amount that is harvested per ha per year, due to differences in intensity between farms. Milk quota per ha is one of the variables of the LV 'Farm size'. It has a negative factor loading. So, from Figure 3 can be concluded that less intense farms, with a high score on the LV 'Farm size', have, on average, a few more growing days. Besides that, data on quantity of silage have to be interpreted with caution, because only the volume was measured. Density of the silage will also differ between farms. It is unknown how these differences in density have influenced the current data. The correlations between growing days for cutting in July and August and amount that is harvested are smaller than for growing days in June. This is in agreement with the factor loadings of the LVs. Number of growing days in June has the highest factor loading. So, the other numbers of growing days are not that crucial.

To support the hypothesis that high-producing farmers cut the grass at too young a stage, the farms have been divided into 3 groups (see Table 7). The division is based on the number of growing days for cutting in June. The numbers are in agreement with the hypothesis. The group in the middle has a number of growing days that is closest to the theoretically optimum of about 28 days (Anonymous, 1997). Compared with the group with fewer growing days they only lose some quality, but they gain quantity and gross margin. The group with the highest number of growing days definitely waits too long; quality of the silage, expressed in VEM and DVE, is lower. Due to that, milk production and gross margin are lower as well. Table 7 also supports the statement that the relationship between growing days and gross margin is not linear, but that an optimum can be found.

\section{Discussion}

The analyses showed that grassland management and feeding management have a reasonable influence on feed costs and on gross margin, whereas the effect on milk production and nitrogen surplus is rather small. The results of the model on nitrogen 
surplus are disappointing. Some influences of feeding and grassland management were expected, but could not be traced. So, no hypotheses could be formulated as to this subject. Hypotheses that are put forward on the relationship between grassland management, feeding management and feed costs are:

1. An increase in percentage of pasture that can be used for grazing will decrease feed costs per $100 \mathrm{~kg}$ of milk. The reason for the worse results of paddocks that cannot be used for grazing, might be that farmers pay less attention to these paddocks. These paddocks ar mostly situated at some distance of the farm, making it hard to include them in the daily management control;

2. The paddock size should be adjusted to realize grazings that do not last longer than 4 days. This will decrease feed costs. Boxem (1982) and Dobbelaar (1988) reasoned that short grazings will limit fluctuations in grass intake and limit the duration of disturbed growth. However, these studies did not include economic data, so they could not prove this hypothesis;

3. Mistakes in this set-up of the paddocks cannot be compensated for by exact planning. Feed costs remain high;

4. Farmers who have organized their grazing management well, also have better results concerning their silage management, resulting in lower feed costs. So, both aspects can be seen as indicators of grassland management in general. This can be the result of the interests of the farmer. Interest in grazing is likely to be related to interest in silage making as well.

The explanatory power of the milk production model was lower than that of the feed costs model. However, one clear hypothesis could be formulated:

5. High milk production per cow is realized on farms with too low a number of growing days for cutting. As a result of that, economic results are below optimal. A farmer who wants to realise a high milk production per cow and wants to reduce feed costs per $100 \mathrm{~kg}$ of milk cannot achieve this by cutting the grass at an early stage. Although this grass has a high energy and protein content, the total yield will be low and additional roughage should be bought. Cutting at a later stage leads to some decrease in energy and protein content, but to higher silage yields. The risk that high milk productions cannot be realised, is somewhat higher, but the feed costs can be reduced. So, a high milk production with a higher gross margin is related to some risks in achieving that production level.. Therefore, a farmer has to take the risk that milk production will not always remain high because of a little lower quality of the silage. That, however, is the only way to combine a high milk production with a high gross margin.

The current study was set up as a cross-sectional study. As a result of that, causes and effects cannot be determined. Only relationships can be measured, and based on logical thinking some hypotheses can be worked out on the underlying causes and effects. Testing these hypotheses needs a different research set-up. To state, for instance, the hypothesis that a high number of grazings lasting longer than 4 days results in higher feed costs, a case-control research has to be set up where farms are studied over a couple of years. In this way, the effect of merely the length of grazing a paddock on economic results can be studied. For each of the hypotheses different research would be necessary. The current study indicates that different steps in deci- 


\section{C.W. ROUGOOR, T.V. VELLINGA, R.B.M. HUIRNE AND A. KUIPERS}

sion making, as defined by Kay \& Edwards (1994), influence economic results: planning (i.e. the variable 'Plan week'), collect information (i.e. the variable 'Know-how VEM'), identify alternative solutions (i.e. the variable 'Feeding aspects').

The results show that a farmer has to take care of the paddock size. When this size is worked out correctly, a good planning of the use of the paddocks, for 4 days in a row at the most, will give the best results.

\section{Acknowledgements}

Contributions of the farmers involved in the study, the NRS and the GIBO group, in making the data available for the study, are gratefully acknowledged.

\section{References}

Anonymous, 1997. Handbook for dairy farming (Dutch). Research Station for Cattle, Sheep and Horse Husbandry. Lelystad, The Netherlands, 520 pp.

Boxem, Tj., 1982. Duration of grazing a paddock: short better than long (Dutch). Bedrijfsontwikkeling 13: 245-248.

Dobbelaar, P., 1988. A proposal for parameters for analysis of grassland management. Proceedings $12^{\text {th }}$ general meeting European Grassland Federation.

Dobbelaar, P., E.A.M. Roosendaal, D.T. Scholl \& A. Brand, 1992. Relationship between the initial sward height and deviations in the grazing period of paddocks on commercial farms. Proceedings $14^{\text {th }}$ general meeting European Grassland Federation, June 8-11, 1992.

Erb, H.N., Martin, S.W., Ison, N., Swaminathan, S., 1981. Interrelationships between production and reproductive diseases in Holstein cows. Path analysis. Journal of Dairy Science 64: 282-289.

Fisher, G.E.J. \& A.M. Dowdeswell, 1995. The performance of summer-calving cows grazing perennial ryegrass swards. Grass and Forage Science 50: 315-323.

Fisher, G.E.J. \& D.J. Roberts, 1995. The effects of stocking rate in spring, and topping on sward characteristics and dairy cow performance in a poor grass growing season. Grass and Forage Science 50: 461-465.

Fornell, C. \& J. Cha, 1994. Partial Least Squares. In: R.P. Bagozzi (Ed.), Advanced methods of marketing research. Blackwell, Cambridge, pp. 52-78.

Fornell, C. \& D.F. Larcker, 1981. Evaluating structural equation models with unobservable variables and measurement error. Journal of Marketing Research 18: 39-50.

Garthwaite, P.H., 1994. An interpretation of Partial Least Squares. Journal of the American Statistical Association 89: 122-127

Gibson, J.P., 1984. The effects of frequency of feeding on milk production of dairy cattle: an analysis of published results. Animal Production 38: 181-189.

Hanson, G.D., L.C. Cunningham, M.J. Morehart \& R.L. Parsons, 1998. Profitability of moderate intensive grazing of dairy cows in the Northeast. Journal of Dairy Science 81: 821-829.

Huirne, R.B.M., S.B. Harsh \& A.A. Dijkhuizen, 1997. Critical success factors and information needs on dairy farms: the farmer's opinion. Livestock Production Science 48: 229-238.

Kay, R.D. \& W.M. Edwards, 1994. Farm Management;.3 ${ }^{\text {rd }}$ ed. McGraw-Hill Inc., New York, 458 pp.

Kristensen, T., J.T. Sørensen \& S. Clausen, 1997. Simulated effect on dairy cow and herd production of different grazing intensities. Agricultural Systems 55: 123-138.

Lohmöller, J.B., 1987. LVPLS 1.8 Program Manual: Latent Variable Path Analysis with Partial Least Squares Estimation. Zentralarchiv für Empirische Sozialforschung der Universität zu Köln. Cologne, $132 \mathrm{pp}$. 
Rougoor, C.W., A.A. Dijkhuizen, R.B.M. Huirne, F. Mandersloot \& Y.H. Schukken, 1997. Relationships between technical, economic and environmental results on dairy farms: an explanatory study. Livestock Production Science 47: 235-244.

Rougoor, C.W., R.B.M. Huirne, A.A. Dijkhuizen \& F. Mandersloot, 1999a. Repeatability in ranking of dairy farms on technical and economic performance over years. Preventive Veterinary Medicine 38: 25-34.

Rougoor, C.W., R. Sundaram \& J.A.M. van Arendonk, 1999b. The relation between breeding management and 305-day milk production determined via Principal Components Regression and Partial Least Squares (submitted to Livestock Production Science).

Rougoor, C.W., G. Trip, R.B.M. Huirne \& J.A. Renkema, 1998. How to define and study farmers' management capacity: theory and use in agricultural economics. Agricultural Economics 18: 261-272.

Sargeant, J.M., K.D. Lissemore, S.W. Martin, K.E. Leslie \& B.W. McBride, 1997. Associations between winter herd management factors and milk protein yield in Ontario dairy herds. Journal of Dairy Science 80: 2790-2802.

Steenkamp, J.B.E.M. \& H.C.M. Van Trijp, 1996. Quality guidance: A consumer-based approach to food quality improvement using partial least squares. European Review of Agricultural Economics 23: 195-215.

Tamminga, S., W.M. Van Straalen, A.P.J. Subnel, R.G.M. Meijer, A. Steg, C.J.G. Wever \& M.C. Blok, 1994. The Dutch protein evaluation system: the DVE/OEB-system. Livestock Production Science 40: 139-155.

Van Es, A.J.H., 1978. Feed evaluation for ruminants. I. The system in use form May 1978 onwards in The Netherlands. Livestock Production Science 5: 331-345.

Waheed, M.A., A.J. Lee \& G.W. Harpestad, 1977. Feeding and management effects on herd differences in milk yield. Journal of Dairy Science 60: 773-782.

Wold, H., 1985. Partial Least Squares. In: S. Kotz \& N.L. Johnson (Eds.), Encyclopedia of Statistical Sciences, Vol. 6. Wiley-Interscience, New York, pp. 581-591. 